\title{
Long Term Performance of Some Spurs and Colour Strains of Apple (Malus domestica Borkh.) under Low Altitude Conditions of Kullu Valley of Himachal Pradesh
}

\author{
J. Kumar", Disha Thakur and Manish Thakur \\ Regional Horticultural Research and Training Station, Dr. Y. S. Parmar University of Horticulture and Forestry \\ P.O. Bajaura, Kullu, Himachal Pradesh (173 230), India
}

\section{Article History}

Manuscript No. AR1482

Received in $27^{\text {th }}$ October, 2015

Received in revised form $24^{\text {th }}$ January, 2016

Accepted in final form $5^{\text {th }}$ February, 2016

\section{Correspondence to}

"E-mail: jayantkumar_in@yahoo.com

\section{Keywords}

Delicious, standard, and spurs and colour strains

\begin{abstract}
The study was undertaken to evaluate the performance of some spur and coloured strains of apple (Malus domestica Borkh.) under low altitude conditions of Kullu valley of Himachal Pradesh. The commercial cultivar Starking delicious introduced in the beginning of the century now does not develop good colour and shape at lower altitude and warmer areas of Himachal Pradesh, due to climate change therefore, two spur cultivars Red Spur and Starkrimsom, four coloured strains Top Red, Vance Delicious, Hardeman and Skyline Supreme Delicious and two spur type pollinizers Stark Spur and Gold Spur grafted on M9 rootstock were compared with commercial cultivar Starking delicious grafted on M9 rootstock at a warmer location Bajaura, Kullu located at an altitude of $1090 \mathrm{~m}$ above MSL. The cultivars Vance delicious and Red Spur developed good colour and fruit shape and ripened 11 and 9 days earlier than Starking delicious. Top Red resulted in the highest trunk girth $(27.0 \mathrm{~cm})$, shoot growth $(17.7 \mathrm{~cm})$ and yield $\left(58.63 \mathrm{tha}^{-1}\right)$ for the last five years followed by Vance delicious with trunk girth $26.2 \mathrm{~cm}$, shoot growth $16.1 \mathrm{~cm}$ and yield $53.64 \mathrm{t} \mathrm{ha}^{-1}$ ). It ripened four days earlier to Starking delicious. Other cultivars ripened simultaneously or later than Starking delicious. Vance delicious appeared to be the most suitable cultivar for lower altitude and marginal areas of Himachal Pradesh and has been recommended for commercial cultivation as it performed well under seasonal variation in temperature and rainfall that occurred during the study period.
\end{abstract}

\section{Introduction}

Starking Delicious is one of the most popular and widely grown cultivars of apple in India. Cultivation of delicious group of apples has changed the socio-economic status of the hill people of Himachal Pradesh. The credit of introduction of these varieties goes to Satya Nand Stokes, an American missionary from USA, who brought delicious group to hill state Shimla, in the first quarter of $20^{\text {th }}$ century. These varieties quickly flourished well in the bright sunshine and warm summers of north Indian hills (Kanwar, 1987). Practically all the Delicious apples which are cultivated in India are the progeny of the plants introduced by Stokes and they constitute $90 \%$ of all the varieties grown in Himachal Pradesh (Jindal et al., 1992). It is well established fact that with the passage of time varieties starts degenerating. These varieties have been grown since very long time and are showing low yield potential and high tendency towards irregular bearing. These are highly sensitive to fluctuating temperatures and rains, particularly at the time of flowering. Little rains or low temperatures results in poor or no fruit set. The other problem with these cultivars is that when tree grow older and bigger in size, the cropping zone gets farther away from the trunk ultimately reducing the yield unit ${ }^{-1}$ area.

Changing climate is posing a great threat to the cultivation of these varieties especially under low altitude conditions and valley area of the state. Fruits of these varieties do not develop good colour and the shape of fruit changes from conical to flat round. This is not a desirable character according to marketing point of view. The solution lies in introducing and growing such strains of delicious apples, which develop good colour, shape and yield heavily under marginal and low altitude areas of the state.

Seedlings from seeds of delicious and Golden delicious apples are commonly used rootstock in Himachal Pradesh. The cultivars grafted on these seedlings plants come into bearing at an age of 10-12 years and the fully grown bearing tree become very vigorous, as a result the orchard operations like pruning, spraying, thinning, harvesting etc. become very 
difficult. Clonal rootstocks are used primarily for reducing tree size, increasing precocity and yield efficiency. Compared with widely spaced large trees, intensive planting of small trees resulting from the use of dwarfing rootstocks intercept more incident light, which is closely related to dry matter production (Jackson, 1980). Smaller trees generally have less internal shading. Shading in fully sized trees results in areas of the tree canopy characterised by low productivity and poor quality (Ferre, 1989) In addition improved light interception and distribution, increased partitioning of photosynthates to fruits rather than wood, also may contribute to high yield efficiencies commonly observed with dwarfed trees (Forshey and McKee, 1970).

Keeping in view the above problems of growing delicious apples, some suitable spur cultivars and standard deep red colour strains of delicious along with spur strains of Golden Delicious were introduced and grafted on M9 rootstock to study their performance under Kullu valley condition.

\section{Materials and Methods}

Two spur delicious cultivars, Red Spur and Starkrimson, four standard delicious strains Top Red, Vance delicious, Hardeman, skyline supreme and two spur type pollinizers Stark Spur and Gold Spur and commercial cultivar Starking Delicious grafted on M9 rootstock were planted during 1998 in the spacing of $1.5 \times 1.75 \mathrm{~m}^{2}$ distance at Regional Horticultural Research and Training Station, Bajaura, Kullu, Himachal Pradesh. The studies were carried out for 5 years. The experiment was laid out in a randomised block design with five replications and three trees in each replication. Row of Tydeman's Early was planted as a pollinizer after every three rows. Bajaura is located at an altitude of $1090 \mathrm{~m}$ amsl. 31.80 $\mathrm{N}$ and 77.20 E on the bank of river Beas in Kullu valley. The summers are hot with maximum temperature rising to $37{ }^{\circ} \mathrm{C}$ and winters are cool with minimum temperature dropping to $-4{ }^{\circ} \mathrm{C}$. The chilling requirement of apple is fully completed.

Data was recorded on bud burst, time and date of flowering and time of harvesting. The cultivars were described according to methods adopted by Bultitude (1984).Yield was calculated as $\mathrm{kg}$ tree $^{-1}$ and tha $\mathrm{a}^{-1}$. Total soluble solid were recorded with Erma hand refractrometer $\left(0-32^{\circ} \mathrm{B}\right)$. Acidity and sugars (reducing and total) were estimated by methods given by AOAC (1980).

Trunk girth was recorded $10 \mathrm{~cm}$ above graft union and shoot length was recorded from current season's growth in the month of December. Yield efficiency was calculated from plant yield and trunk cross sectional area as method given by Westwood (1993).

\section{Results and Discussion}

\subsection{Flowering}

In spite of seasonal variation in temperate and rainfall the deep red coloured strains of standard cultivar Vance Delicious was earliest to break dormancy ( $4^{\text {th }}-7^{\text {th }}$ March) followed by Top Red $\left(5^{\text {th }}-8^{\text {th }}\right.$ March $)$ and Hardeman $\left(7^{\text {th }}-10^{\text {th }}\right.$ March $)$. Skyline Supreme and commercial apple cultivar Starking Delicious break their dormancy during $9^{\text {th }}-12^{\text {th }}$ March. Whereas spur type cultivars Red Spur, Starkrimson, Stark Spur and Gold Spur break their dormancy later. (Table 2). This variation is noticed due to fluctuation in temperature, as the plant is not able to receive the adequate chilling hours required (800-1100 hr) to resume normal spring growth. Among colour strains

\begin{tabular}{|c|c|c|c|c|c|c|c|c|c|c|c|c|c|c|c|}
\hline \multirow[t]{2}{*}{ Month } & $\begin{array}{c}\mathrm{T}- \\
\max \end{array}$ & $\begin{array}{c}\mathrm{T}- \\
\mathrm{min}\end{array}$ & $\begin{array}{c}\text { Rain } \\
\text { fall }\end{array}$ & $\begin{array}{c}\mathrm{T}- \\
\max \end{array}$ & $\begin{array}{c}\mathrm{T}- \\
\mathrm{min}\end{array}$ & $\begin{array}{c}\text { Rain } \\
\text { fall }\end{array}$ & $\begin{array}{c}\mathrm{T}- \\
\max \end{array}$ & $\begin{array}{c}\mathrm{T}- \\
\mathrm{min}\end{array}$ & $\begin{array}{c}\text { Rain } \\
\text { fall }\end{array}$ & $\begin{array}{c}\mathrm{T}- \\
\max \\
\end{array}$ & $\begin{array}{c}\mathrm{T}- \\
\mathrm{min}\end{array}$ & $\begin{array}{l}\text { Rain } \\
\text { fall }\end{array}$ & $\begin{array}{c}\mathrm{T}- \\
\max \end{array}$ & $\begin{array}{c}\mathrm{T}- \\
\mathrm{min}\end{array}$ & $\begin{array}{c}\text { Rain } \\
\text { fall }\end{array}$ \\
\hline & \multicolumn{3}{|c|}{2008} & \multicolumn{3}{|c|}{2009} & \multicolumn{3}{|c|}{2010} & \multicolumn{3}{|c|}{2011} & \multicolumn{3}{|c|}{2012} \\
\hline Jan & 13.4 & 0.8 & 88.4 & 15.5 & 1.5 & 207.4 & 18.1 & 0.1 & 1.0 & 12.5 & 1.0 & 246.1 & 17.3 & 3.0 & 26.9 \\
\hline Feb & 14.8 & 2.0 & 284.3 & 21.7 & 5.8 & 48.9 & 17.0 & 3.5 & 233.4 & 18.0 & 2.0 & 60.2 & 19.4 & 4.30 & 51.3 \\
\hline March & 20.6 & 5.7 & 211.6 & 22.1 & 5.3 & 109.4 & 21.7 & 4.0 & 240.8 & 24.8 & 6.2 & 7.2 & 23.0 & 6.0 & 69.0 \\
\hline April & 24.8 & 8.0 & 8.9 & 26.1 & 8.5 & 48.0 & 29.6 & 10.7 & 5.2 & 25.5 & 8.7 & 80.7 & 26.6 & 8.6 & 39.8 \\
\hline May & 27.5 & 9.8 & 63.4 & 30.3 & 13.6 & 64.5 & 29.9 & 12.4 & 55.2 & 29.4 & 12.2 & 99.0 & 28.7 & 11.1 & 30.9 \\
\hline June & 33.0 & 13.9 & 52.5 & 30.4 & 15.5 & 24.9 & 31.4 & 17.1 & 67.3 & 29.8 & 18.5 & 131.0 & 33.1 & 13.8 & 31.9 \\
\hline July & 29.3 & 19.2 & 245.4 & 30.6 & 20.1 & 138.6 & 30.2 & 19.9 & 125.3 & 30.3 & 20.5 & 82.8 & 32.4 & 16.6 & 30.2 \\
\hline August & 30.4 & 18.9 & 42.5 & 30.2 & 19.1 & 122.3 & 30.0 & 20.0 & 135.7 & 28.7 & 18.8 & 199.7 & 31.1 & 19.3 & 131.9 \\
\hline Sept & 28.6 & 16.0 & 118.3 & 29.5 & 15.4 & 64.1 & 30.2 & 16.5 & 32.3 & 27.7 & 13.3 & 146.9 & 28.1 & 13.7 & 131.3 \\
\hline Oct & 26.9 & 8.3 & 1.6 & 26.5 & 9.4 & 21.1 & 28.0 & 8.5 & 8.0 & 26.0 & 8.8 & 43.6 & 26.9 & 7.6 & 1.3 \\
\hline Nov & 22.1 & 2.4 & 0.5 & 21.8 & 4.9 & 22.5 & 23.4 & 3.6 & 0.3 & 22.8 & 3.9 & 2.4 & 20.7 & 3.3 & 31.1 \\
\hline Dec & 18.5 & -0.2 & 0.0 & 17.0 & 1.6 & 61.0 & 17.4 & 1.0 & 25.0 & 19.4 & 2.8 & 61.7 & 17.1 & 7.2 & 7.2 \\
\hline
\end{tabular}


Top Red was first to open its flowers $\left(22^{\text {nd }}-24^{\text {th }}\right.$ March $)$, followed by Vance Delicious (24 ${ }^{\text {nd }}-26^{\text {th }}$ March) , Hardeman ( $25^{\text {th }}-28^{\text {th }}$ March) and Skyline Supreme $\left(25^{\text {th }}-28^{\text {th }}\right.$ March) .Whereas in case of spur cultivars Red spur was first to open its flowers ( $25^{\text {th }}-28^{\text {th }}$ March $)$ followed by Starkrimson ( $30^{\text {th }}$ March-2 $2^{\text {nd }}$ April) and Stark Spur ( $31^{\text {st }}$ March-2 $2^{\text {nd }}$ April). Gold Spur was last to open its flower. Commercial cultivar Starking Delicious also opens its flower late in the season. The deep red colour strains of standard cultivar Top Red, Vance Delicious, Hardeman showed full bloom earlier in the season i.e. on $31^{\text {st }}$ March, Whereas Skyline Supreme showed full bloom later in the season. Stark Spur and Gold Spur took the longest time from bud burst to full bloom. Red Spur and Starkrimson took least time. This variation in time and duration of flowering was due to fluctuation in temperature and rainfall during winter and spring season.

Top Red had the longest and Starkrimson had the shortest duration of flowering. This was probably due to difference in size and compact habit of Starkrimson trees. The blooming period of delicious varieties and pollinizers Gold Spur and Stark Spur did not coincide well and the pollinizers blossomed five days later than delicious varieties. More or less similar synchronization problem existed in pollination of Starking Delicious and Golden Delicious (Petersons, 1989), although Roberts (1947) had reported Golden Delicious to be one of the best pollinizers for delicious in North America and South East Canada. Hence these cannot be considered to be ideal pollinizers. Since there were large numbers of cultivars close to the experimental plantation the yield of rest cultivars may not be affected due to delayed flowering of pollinizers.

\subsection{Fruit Maturity}

Data in Table 1 revealed that all cultivars either that of red colour strains of standard cultivar or of spur cultivars exhibited the same general response under fluctuating temperate and rainfall patterns, except that of cultivar Vance Delicious. Vance Delicious was earliest to ripen on $14^{\text {th }}$ August. However, it could be harvested earlier due to development of good colour

Table 2: Time and duration of flowering, days from flowering to harvest of various spur and standard Delicious and spur Golden Delicious cultivars of apple

\begin{tabular}{|c|c|c|c|c|c|c|c|c|c|}
\hline Cultivars & $\begin{array}{l}\text { Date of } \\
\text { bud burst } \\
\text { Month }^{-1}\end{array}$ & $\begin{array}{c}\text { Date } \\
\text { of first } \\
\text { flower to } \\
\text { open } \\
\text { Month }^{-1}\end{array}$ & $\begin{array}{l}\text { Date of } \\
\text { full bloom- } \\
\text { Month }^{-1}\end{array}$ & $\begin{array}{c}\text { Date of } \\
\text { petal fall } \\
\text { Month }^{-1}\end{array}$ & $\begin{array}{c}\text { Days from } \\
\text { bud burst to } \\
\text { first flower } \\
\text { opening } \\
\text { Month }^{-1}\end{array}$ & $\begin{array}{c}\text { Duration } \\
\text { of } \\
\text { flowering } \\
\text { Days }\end{array}$ & $\begin{array}{c}\text { Date of co- } \\
\text { lour devel- } \\
\text { opment } \\
\text { Month }^{-1}\end{array}$ & $\begin{array}{c}\text { Mid } \\
\text { date of } \\
\text { harvest } \\
\text { Month }^{-1}\end{array}$ & $\begin{array}{r}\text { Days } \\
\text { from } \\
\text { flower- } \\
\text { ing to } \\
\text { harvest }\end{array}$ \\
\hline \multicolumn{10}{|c|}{ Deep red colour strains of standard cultivars } \\
\hline Top Red & $05 / 3$ & $22 / 3$ & $31 / 3$ & $08 / 4$ & 17 & 17 & $20 / 8$ & $23 / 8$ & 145 \\
\hline $\begin{array}{l}\text { Vance } \\
\text { Delicious }\end{array}$ & $04 / 3$ & $24 / 3$ & $31 / 3$ & $06 / 4$ & 20 & 13 & $31 / 7$ & $14 / 8$ & 136 \\
\hline $\begin{array}{l}\text { Harde- } \\
\text { man }\end{array}$ & $07 / 3$ & $25 / 3$ & $31 / 3$ & $06 / 4$ & 18 & 12 & $22 / 8$ & $26 / 8$ & 148 \\
\hline $\begin{array}{l}\text { Skyline } \\
\text { Supreme }\end{array}$ & $09 / 3$ & $25 / 3$ & $02 / 4$ & $06 / 4$ & 16 & 12 & $23 / 8$ & $26 / 8$ & 146 \\
\hline \multicolumn{10}{|c|}{ Spur strain of delicious } \\
\hline $\begin{array}{l}\text { Starkrim- } \\
\text { son }\end{array}$ & $10 / 3$ & $30 / 3$ & $01 / 4$ & $06 / 4$ & 20 & 8 & $4 / 8$ & $20 / 8$ & 141 \\
\hline Red Spur & $10 / 3$ & $25 / 3$ & $31 / 3$ & $04 / 4$ & 15 & 10 & $4 / 8$ & $17 / 8$ & 139 \\
\hline \multicolumn{10}{|c|}{ Spur strain of golden delicious } \\
\hline $\begin{array}{l}\text { Stark } \\
\text { Spur }\end{array}$ & $10 / 3$ & $31 / 3$ & $06 / 4$ & $12 / 4$ & 21 & 13 & $27 / 8$ & $01 / 9$ & 148 \\
\hline $\begin{array}{l}\text { Gold } \\
\text { Spur }\end{array}$ & $10 / 3$ & $01 / 4$ & $06 / 4$ & $12 / 4$ & 22 & 12 & $2 / 9$ & $09 / 9$ & 156 \\
\hline \multicolumn{10}{|c|}{ Commercial Standard cultivar } \\
\hline $\begin{array}{l}\text { Starking } \\
\text { Delicious }\end{array}$ & $09 / 3$ & $27 / 3$ & $01 / 4$ & $07 / 4$ & 18 & 11 & $22 / 8$ & $25 / 8$ & 146 \\
\hline
\end{tabular}

${ }^{*}$ Data presented is the mean of five year (2008-12) 
around $31^{\text {st }}$ July. It took 136 days to ripen from full bloom to harvest. This was followed by Top red which is ready to harvest on $23^{\text {rd }}$ August. It took 145 days to ripen from full bloom to harvest, Whereas spur cultivars Red Spur was ready to harvest on 17 August. All other cultivars Starkrimsom, Top Red, Skyline Supreme, Starking Delicious, Stark Spur and Gold Spur ripen late and took 148 and 151 days to ripen from full bloom, respectively. Sharma and Karkara (2004) have also reported that cv. Vance Delicious ripened 10 to 15 days earlier than Starking Delicious. This can be attributed to delayed bloom that occurred during the study period as a result of lack of chilling and the resulting warmer temperatures experienced during early fruit development. Higher and fluctuating temperatures during the early stages of fruit development have been shown to affect the fruit development and ultimately fruit maturity. As the duration of cell division, assessed indirectly by measuring expansion rate, appeared to be inversely related to mean temperature (i.e., prolonged under cooler conditions)

\subsection{Bearing Habit}

All the cultivars were found to bear fruits laterally on spurs rather than terminally on long shoots. Red Spur, Starkrimson, Stark Spur and Gold Spur were compact types. They had more number of spurs per unit shoot length than other cultivars (Table 3). Starkrimson had the highest number of spurs $\left(36.2 \mathrm{~m}^{-1}\right)$ followed by Red spur $\left(31.9 \mathrm{~m}^{-1}\right)$. Ketchie (1984) assessed 17 strains of Delicious apples on seedlings rootstock at Columbia, Washington State and reported that spur types had a significantly higher spur density than standard types. Warrington et al. (1990) characterised the features of spur type strains of delicious apple and reported that spur types have more compact growth form and associated upright branch habits, compared with the more open canopy form of standard strains. Consequently, spur type strain can be planted closer together to maximize canopy development unit ${ }^{-1}$ land area.

Studies on spur characters revealed that Red spur have the highest bud diameter, more number of leaves per spur, fresh and dry weight of leaves and leaf area followed by Starkrimson and the lowest with Starking Delicious. The improved colour strains of strand cultivar Top Red and Vance Delicious had significantly higher bud diameter, number of leaves per spur, fresh and dry weight of leaves and leaf area than commercial cultivars Starking Delicious. This variation in bud and leaf characteristics is due to alteration of phenology in plants as a result of long-term climate change.

\subsection{Growth}

The highest trunk girth $(27.0 \mathrm{~cm})$ and shoot length 17.7 $\mathrm{cm})$ was observed with cultivar Top Red followed by Vance Delicious $(27.3 \mathrm{~cm}$ and $16.1 \mathrm{~cm})$ (Table 4). These cultivars are vigorous or standard type. Warrington et al. (1990) also observed higher trunk girth of cultivar Top Red on M9 rootstock at Michigan State University and West Virginia University in USA. The lowest trunk girth and shoot length in standard varieties was observed with Hardeman $(22.6 \mathrm{~cm}$ and $13.9 \mathrm{~cm})$ ). In spur type strains cv. Red Spur had the highest trunk girth $(25.6 \mathrm{~cm})$ and shoot length $(14.1 \mathrm{~cm})$. The lowest trunk girth $(14.7 \mathrm{~cm})$ and annual shoot growth $(2.9 \mathrm{~cm})$ was recorded with Starkrimson. The growth of these cultivars was very low and their canopies were also small and could not even occupy the space provided to them.

\begin{tabular}{lcccccc}
\hline \multicolumn{6}{l}{ Table 3: Bud and leaf characters of various spur and standard cultivars of Delicious apples on M9 rootstock } \\
\hline Cultivars & $\begin{array}{c}\text { Bud diam- } \\
\text { eter (mm) }\end{array}$ & $\begin{array}{c}\text { No. of } \\
\text { leaves spur }\end{array}$ & $\begin{array}{c}\text { Fresh weight } \\
\text { of leaves (g) }\end{array}$ & $\begin{array}{c}\text { Dry weight } \\
\text { of leaves }(\mathrm{g})\end{array}$ & $\begin{array}{c}\text { Leaf area } \\
\left(\mathrm{cm}^{2}\right)\end{array}$ & $\begin{array}{c}\text { Number of spurs m } \\
\text { shoot length }\end{array}$ \\
\hline Top Red (St) & 3.7 & 6.3 & 0.41 & 0.18 & 13.1 & 24.16 \\
Vance Delicious (St) & 3.5 & 6.2 & 0.32 & 0.15 & 14.2 & 25.43 \\
Hardeman (St) & 2.9 & 5.8 & 0.27 & 0.12 & 12.4 & 24.03 \\
Skyline Supreme (St) & 2.9 & 5.6 & 0.31 & 0.14 & 13.8 & 24.85 \\
Starkrimson (Sp) & 3.8 & 8.5 & 0.42 & 0.20 & 14.2 & 36.24 \\
Red Spur (Sp) & 4.2 & 7.8 & 0.51 & 0.24 & 16.6 & 31.93 \\
Gold Spur (Sp) & 3.1 & 6.6 & 0.34 & 0.13 & 12.3 & 10.36 \\
Stark Spur (Sp) & 3.1 & 6.5 & 0.35 & 0.13 & 12.1 & 19.93 \\
Starking Delicious (Cs) & 2.8 & 5.7 & 0.24 & 0.11 & 9.70 & 16.13 \\
SEm \pm & 0.04 & 0.03 & 0.01 & 0.02 & 0.2 & 1.10 \\
CD $(p=0.05)$ & 0.18 & 0.17 & 0.03 & 0.01 & 0.40 & 2.44 \\
\hline
\end{tabular}

*Data presented is the mean of five year (2008-12)

St: Deep Red colour strains of standard cultivars; Sp: Spur strain of Delicious and Golden Delicious; Cs: Commercial Standard cultivar 


\begin{tabular}{|c|c|c|c|c|c|c|c|c|c|c|c|c|}
\hline \multirow[t]{2}{*}{ Cultivars } & \multicolumn{5}{|c|}{ Trunk girth $(\mathrm{cm})$} & \multirow[t]{2}{*}{ Avg. } & \multicolumn{5}{|c|}{ Shoot length $(\mathrm{cm})$} & \multirow[t]{2}{*}{ Avg } \\
\hline & 2008 & 2009 & 2010 & 2011 & 2012 & & 2008 & 2009 & 2010 & 2011 & 2012 & \\
\hline Top Red (St) & 26.1 & 26.4 & 26.9 & 27.4 & 28.3 & 27.0 & 20.4 & 16.8 & 17.4 & 17.0 & 16.9 & 17.7 \\
\hline Vance Delicious (St) & 25.3 & 25.7 & 26.2 & 26.6 & 27.3 & 26.2 & 17.8 & 16.3 & 15.9 & 15.5 & 15.6 & 16.1 \\
\hline Hardeman (St) & 21.8 & 22.1 & 22.4 & 23.0 & 23.9 & 22.6 & 16.6 & 12.6 & 12.7 & 12.5 & 12.4 & 13.9 \\
\hline Skyline Supreme (St) & 22.2 & 22.3 & 22.6 & 23.3 & 24.3 & 22.7 & 18.2 & 12.5 & 13.0 & 12.9 & 13.6 & 14.0 \\
\hline Starkrimson (Sp) & 14.1 & 14.4 & 14.6 & 15.0 & 15.6 & 14.7 & 3.2 & 3.0 & 2.9 & 2.9 & 2.4 & 2.9 \\
\hline Red Spur (Sp) & 24.8 & 25.3 & 25.7 & 25.9 & 26.6 & 25.6 & 16.7 & 13.6 & 13.8 & 13.6 & 12.8 & 14.1 \\
\hline Gold Spur (Sp) & 24.1 & 24.4 & 24.7 & 25.4 & 26.3 & 24.9 & 16.1 & 13.4 & 13.7 & 13.6 & 12.4 & 13.8 \\
\hline Stark Spur (Sp) & 16.5 & 17.8 & 18.1 & 18.3 & 18.7 & 18.0 & 3.5 & 3.4 & 3.4 & 3.2 & 2.7 & 3.2 \\
\hline Starking Delicious (Cs) & 24.3 & 24.7 & 24.9 & 25.3 & 26.4 & 25.1 & 20.5 & 16.3 & 16.2 & 15.9 & 15.5 & 16.9 \\
\hline $\operatorname{SEm} \pm$ & 0.10 & 0.9 & 0.9 & 0.10 & 0.07 & 0.52 & 0.66 & 0.12 & 0.13 & 0.13 & 0.9 & 0.94 \\
\hline $\mathrm{CD}(p=0.05)$ & 0.31 & 0.29 & 0.29 & 0.31 & 0.23 & 1.80 & 1.99 & 0.34 & 0.38 & 0.38 & 0.29 & 2.06 \\
\hline
\end{tabular}

*Data presented is the mean of five year (2008-12)

St: Deep Red colour strains of standard cultivars; Sp: Spur strain of Delicious and Golden Delicious; Cs: Commercial Standard cultivar

\subsection{Yield}

Average yield for five years were highest with cv. Top Red (15.39 kg tree ${ }^{-1}$ and $\left.58.63 \mathrm{t} \mathrm{ha}^{-1}\right)$ followed by Vance Delicious (14.08 $\mathrm{kg}$ tree $^{-1}$ and $\left.53.6 \mathrm{t} \mathrm{ha}^{-1}\right)$. Top Red also had the highest yield efficiency $(24.9 \%)$, followed by Vance Delicious $(24.20 \%)$ in compared with most popular cv. Starking Delicious (21.94\%). The yield of Top Red and Vance Delicious were $32.67 \%$ and $21.35 \%$ higher than Starking Delicious, respectively. Both these cultivars were regular and highly productive. Warrington (1990) has also reported high production of $\mathrm{cv}$. Top Red. The perusal of data (Table 5) reveals that fruit yield of different cultivars followed a decreasing/ increasing pattern during the study period. This decreasing/increasing pattern in apple yield may be due to due to unusual seasonal fluctuation in temperature and unusual rain fall pattern during the period. The changing temperature and radiation pattern leads to decrease/increase or to the stagnation of yield (Supit et al., 2010). The abrupt change in weather pattern resulted in decreased yield and some time it declines to zero. Extreme weather conditions like strong wind and rainfall causes removal of top soil in short duration thus destroying soil capability to support vegetation (Neilson and Neilson, 2003).

In spur type the highest yield was observed with Red Spur (12.5 $\mathrm{kg}$ tree $^{-1}$ ) and the lowest yield among all the cultivars were recorded with Starkrimson (4.19 kg tree $\left.{ }^{-1}\right)$. The Starkrimson had the lowest trunk cross-sectional area, trunk girth, shoot length and yield efficiency. Warrington (1990) reported that Red Spur had the highest yield amongst spur type plantation of apple on M7 rootstock. M9 rootstock did not appear to be suitable rootstock for spur type strains of Delicious apples.
The canopy of spur type of apples on M9 rootstock planted at a spacing of $1.5 \times 1.75 \mathrm{~m}^{2}$ was small and their spread was also small resulting in low yield plant ${ }^{-1}$. They could be planted at a spacing of $1 \times 1 \mathrm{~m}^{2}$ and their production will be $70 \%$ more when compared to standard apples.

Two spur type pollinizers viz., Stark Spur and Gold Spur appeared to be promising as far as growth and yield were concerned.

\subsection{Fruit characters}

The data presented in Table 6 indicate that among deep red coloured strains of standard cultivars. The highest fruit length, breadth and weight were recorded with cv. Top Red $(7.34 \mathrm{~cm}, 8.33 \mathrm{~cm}$ and $243 \mathrm{~g}$, respectively) followed by Vance Delicious, Skyline Supreme and Hardeman, Whereas Starking Delicious has lowest fruit length, breadth and weight. In case of spur cultivars the highest fruit length, breadth and weight were recorded with Red Spur $(7.12 \mathrm{~cm}, 7.85 \mathrm{~cm}$ and $208 \mathrm{~g}$, respectively) and lowest fruit length, breadth and weight were recorded with Stark Spur $(6.45 \mathrm{~cm}, 7.64 \mathrm{~cm}$ and $175 \mathrm{~g}$, respectively). Rest of the Gold Spur and Starkrimson also had medium to large fruits. From the studies it is clear that in spite of seasonal variations the apple cultivars Top Red, Vance Delicious and Hardeman develop good fruit colour (dark red colour with stripes) where the commercial cultivar Starking Delicious failed to do so. Contrary to the observations Skyline Supreme had broken stripe with dark red colour (Table 6) and not solid red colour as indicated by Brooks and Olmo (1972). Red Spur and Starkrimson had dark red blush without any stripes, but with more prominent dots.

Under low altitude conditions, due to fluctuation of day and 


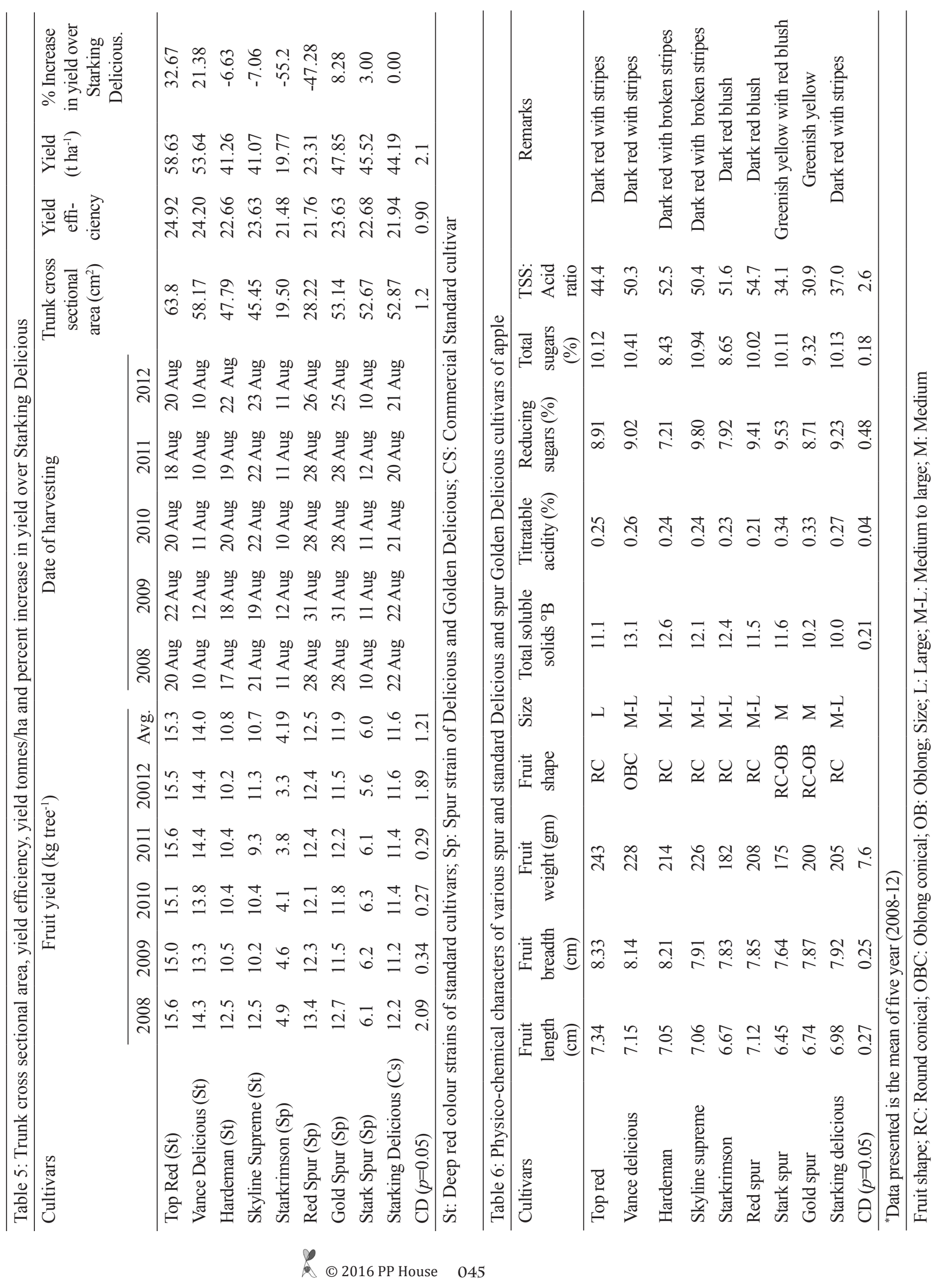


night temperature the fruits of all the delicious cultivars turned round conical except in case of Vance Delicious, that had oblong conical fruits; this is a desirable character according to the market value of the fruit. All the delicious cultivars were sweet in taste.

Under changing climatic conditions, the cultivar Vance delicious had recorded maximum total soluble solids $\left(13.1^{\circ} \mathrm{B}\right)$, reducing sugars $(9.02 \%)$ and total sugars $(10.41 \%)$. The lowest total soluble solids were recorded with Gold Spur $\left(10.2^{\circ} \mathrm{B}\right)$. The highest Titratable acidity was recorded with cv. Stark Spur. Delicious varieties generally had less acidity.

\section{Conclusion}

Cultivars Vance Delicious and Red Spur developed good colour and fruit shape and ripened 11 and 9 days earlier than Starking Delicious. Thus Vance Delicious and Red Spur appeared to be the most suitable cultivar for lower altitude and marginal areas of Himachal Pradesh and have been recommended for commercial cultivation as it performed well under seasonal variation in temperature and rainfall that occurred during the study period.

\section{Reference}

A.O.A.C., 1980. Official Methods of Analysis of the Association of Analytical Chemistry. Washington D C., 1018.

Brooks, R.M., Olmo, H.P., 1972. Register of new fruit and nut varieties. Uni. Calif. Press, 708.

Bultitude, J., 1984. Identification of apples. In: Apple- a Guide to the identification of International Varieties, Mc Millan Press, London, 11.

Ferre, D.C., 1989. Influence of orchard management systems on spur quality, light and fruit within the canopy of
Golden Delicious apple trees. Journal of the American Society for Horticultural Sciences 114, 869-875.

Forshey, C.G., McKee, M.W., 1970. Production efficiency of large and small Mc in Tosh apple tree. Hort Science $5,164-165$

Jackson, J.E., 1980. Light interception and utilization by orchard systems. Hort Review 2, 208-267.

Jindal, K.K., Karkra, B.K., Sharma, B.K., Uppal, D.K., 1992. Evaluation of spur types and colour strains of apple. In: Chadha, K.L., Uppal, D.K., Pal, R.N., Awasthi, R.P., Ananda, S.A. (Eds.), Emerging trends in temperate fruit production in India, NHB Tecth. Commun., Gurgaon, India, 39-40.

Kanwar, S.M., 1987. Apple production technology and economics. Tata McGraw Hill, New Delhi, 899.

Ketchie, D.O., 1984. Flowering, spur formation and limb angle of Delicious strains. Fruit Variety Journal 38, 150-152.

Peterson, B., 1989. Orchard system for spur Delicious. Good Fruit Grower 40, 4-9.

Roberts, R.H., 1947. Notes on the setting of Delicious. Proceeding of the American Society of Horticultural Sciences 50, 85-94.

Sharma, R.P., Karkara, B.K., 2004. Performance of some cultivars of Delicious apple in low warm areas of Shimla. Acta Horticulturae 662, 175-7.

Warrington, I.J., Ferree, D.C., Schupp, J.R., Dennis, F.G. Jr., Baugher, T.A., 1990. Strain and rootstock effects on spur characteristics and yield of Delicious strains. Journal of American Society of Horticultural Sciences 115, 348-356.

Westwood, M.U., 1993. Temperate Zone Pomology. Timber Press Portland Oregon, 278-299. 